\title{
Minerals and Electrolytes Status in Cows Fed on Rations Supplemented with Anionic Salts in Pre-Partum Period in Prevention of Milk Fever
}

\author{
Arindam Bhowmik ${ }^{1 *}$, Gunjan Das ${ }^{2}$, Hriyadesh Prasad ${ }^{1}$, Kalyan Sarma $^{1}$, \\ A.K. Samanta ${ }^{3}$, Bikash Debnath ${ }^{4}$, J. K. Chaudhary ${ }^{5}$, Prasenjit Debnath ${ }^{1}$, \\ Albert Debbarma $^{1}$ and Moneesh Thakur ${ }^{1}$
}

${ }^{1}$ Department of Veterinary Medicine, ${ }^{3}$ Department of Animal Nutrition, ${ }^{5}$ Department of Animal Breeding \& Genetics, College of Veterinary Sciences and Animal Husbandry, Selesih, Aizawl, Central Agriculture University, Mizoram-796015, India

${ }^{2}$ Department of Veterinary Medicine, College of Veterinary Sciences and Animal Husbandry, Jalukie, Peren district, Central Agriculture University, Nagaland-797110, India

${ }^{4}$ Department of Animal Nutrition, College of Veterinary Sciences and Animal Husbandry, R. K. Nagar, West Tripura, Tripura University, Tripura-799008, India

*Corresponding author

Keywords

Milk Fever, DCAD,

Dry Matter,

Calcium, Anionic

salt preparations

Article Info

Accepted:

20 June 2019

Available Online:

10 July 2019

\section{A B S T R A C T}

Eighteen animals were engaged for therapeutic trial with three groups (Group 1; Control, Group 2; Mixture of Ammonium Chloride and Calcium Sulphate at 1:1 ratio and Group 3; Commercial salts preparation, Hyporid $^{\mathrm{TM}}$ ) containing six animals each. The efficacy of various anionic salt preparations was determined on the basis of haemato-biochemical changes and incidence of milk fever after calving. Dietary Cation-Anion Difference (DCAD) concentration in control group was positive $(+25.22$ $\mathrm{mEq} / 100 \mathrm{gm}$ of dry matter). After adding anionic salt preparation DACD concentrations were negative in both Group $2(-11.44 \mathrm{mEq} / 100 \mathrm{gm}$ of dry matter) and Group $3(-8.26 \mathrm{mEq} / 100 \mathrm{gm}$ of dry matter). In this therapeutic study, milk fever incidence rate was $33.33 \%$ (2/6) in control group whereas no occurrence of milk fever was reported in Group 2 and Group 3. The mean value of calcium, phosphorus, chloride and sulphate was significantly lower $(p<0.05)$ with significant increase $(p<0.05)$ in mean value of magnesium and sodium in Group 1 compared to Group 2 and Group 3 after calving. 


\section{Introduction}

Milk fever, also known as Parturient Paresis or Hypocalcemia is one of the most economically important production diseases in dairy cows. It has a substantial impact on animal production (Curtis et al., 1985). It is an acute to peracute, afebrile, flaccid circulatory condition occurs most commonly in high-producing adult lactating dairy cattle. Lactating beef cows are less commonly affected. On the other hand mature dairy cows are most commonly affected in the age group 5-10 years. The hypocalcemia at calving is also age related factor and most marked in cows at their $3^{\text {rd }}$ to $7^{\text {th }}$ parturition (Radostits et al., 2006). Cows with milk fever produced less than nonaffected cows for the first 4-6 weeks of lactation but over a whole lactation produced more milk than non-affected cows (RajalaSchultz et al., 1999).

Dietary cation-anion difference, or DCAD, is a measure used in both dry and lactating cow as regards to the metabolic status of the animal is concerned. In close-up dry cows, a negative DCAD can help prevent metabolic problems and in lactating cows, a positive DCAD can help increase milk production and milk components. The most common strategy employed to achieve this negative DCAD is the addition of anionic salts to the diet of pre calving cattle (Goff et al., 2004).

The dietary cation-anion difference exerts a strong, linear effect on the incidence of milk fever. The DCAD balance in the pre-partum diet may be more important than the level of dietary calcium as a risk factor for milk fever. Pre-partum diets high in cations such as sodium and potassium are associated with an increased incidence of milk fever, while diets high in anions, especially chloride and sulfur are associated with a decrease incidence of the disease. Alkaline diets containing an excessive concentration of sodium and potassium can result in an increased incidence of the disease. Most forages such as legumes and grasses are high in potassium and are alkaline that may lead to metabolic alkalosis predisposing cows to milk fever. Under most circumstances the alkalosis is induced by the potassium in the diet (Goff and Horst, 2003).

\section{Materials and Methods}

In this study, 3 groups (Group 1, Group 2 and Group 3) of animals were taken with 6 no of animals in each group. Two types of anionic salts were used i.e. a mixture of Ammonium Chloride and Calcium Sulphate at 1:1 ratio and commercial anionic salt preparation Hyporid $^{\mathrm{TM}}$. Group 1 was control group. Group 2 and Group 3 were fed with Ammonium Chloride and Calcium Sulphate and Hyporid $^{\mathrm{TM}}$, respectively for 3 weeks before expected date of calving.

Blood samples were collected on 14 days before expected date of parturition, within 2 days of parturition and 30 days after parturition. Serum samples were evaluated for the concentrations of Calcium, Sodium, Potassium, Chloride, Sulphate, Magnesium and Phosphorus. All these parameters were determined by spectrophotometric method (Microprocessor UV/VIS Spectrophotometer) using commercially available test kits and following the manufacturer's instructions.

\section{Results and Discussion}

Therapeutic efficacy of anionic salts and commercial salt preparation (Hyporid ${ }^{\mathrm{TM}}$ ) in management of milk fever is shown in Table 1 and 2. In this study, 3 groups (Group 1, Group 2 and Group 3) of animals were taken having 6 no of animals in each group. Two types of anionic salts were used i.e. a mixture of Ammonium Chloride and Calcium Sulphate at $1: 1$ ratio and commercial anionic salt preparation Hyporid $^{\mathrm{TM}}$. Group 1 was control 
group. Group 2 and Group 3 were fed with Ammonium Chloride and Calcium Sulphate and Hyporid $^{\mathrm{TM}}$, respectively at the rate of $90 \mathrm{gm}$ twice a day for 3 weeks before expected date of calving.

After oral administration of these anionic salts supplementation, DCAD concentration level in feeds were $-11.44 \mathrm{mEq} / 100 \mathrm{gm}$ of $\mathrm{DM}$ incase of Group 2 and - $8.26 \mathrm{mEq} / 100 \mathrm{gm}$ of DM incase of Group 3. Since Group 1 was control group, no anionic salt preparation added in feeds. As a result DCAD concentration was $+25.22 \mathrm{mEq} / 100 \mathrm{gm}$ of DM. Milk fever incidences in therapeutic trial were $33.33 \%$ in Group 1 and $0 \%$ in both Group 2 and Group 3 as depicted in Table 2. Similar findings also reported by Seifi et al., (2010), that diets with excess anions through anionic salts supplementation prevented milk fever, and diets with a relative excess of cations predisposed cows to milk fever. According to Gelfert et al., (2010), low DCAD diets induced a mild, compensated metabolic acidosis.

Low DCAD by adding anionic salts improved $\mathrm{Ca}$ homeostasis by induced moderate metabolic acidosis in body where receptors for PTH became more efficient. PTH hormone is necessary for reabsorption of $\mathrm{Ca}$ from bones when there is sudden fall in Ca level in blood after parturition to prevent milk fever.

The mean \pm S.E. of minerals ( $\mathrm{Ca}, \mathrm{P}$ and $\mathrm{Mg}$ ) and Electrolytes status ( $\mathrm{Na}, \mathrm{K}, \mathrm{Cl}$ and $\mathrm{S}$ ) are depicted in Table 3.

The serum Calcium (Ca) level in Group 1 cows on day $-14,+2$ and +30 were $7.81 \pm 0.10$, $6.90 \pm 0.13$ and $7.30 \pm 0.17 \mathrm{mg} / \mathrm{dl}$, respectively. The Ca level in Group 2 cows on day -14 . +2 and +30 were $9.46 \pm 0.18,8.78 \pm 0.16$ and $9.80 \pm 0.24 \mathrm{mg} / \mathrm{dl}$, respectively. The Ca level in Group 3 cows on day $-14,+2$ and +30 were $9.70 \pm .0 .26,9.81 \pm 0.24$ and $10.60 \pm 0.18 \mathrm{mg} / \mathrm{dl}$, respectively. There were significant differences $(\mathrm{p}<0.05)$ within as well as between groups on day $-14,+2$ and +30 .

The serum Phosphorus (P) level in Group 1 cows on day $-14,+2$ and +30 were $7.13 \pm 0.08$, $5.60 \pm 0.10$ and $6.45 \pm 0.31 \mathrm{mg} / \mathrm{dl}$, respectively. The P level in Group 2 cows on day -14 . + 2 and +30 were $7.10 \pm 0.09,6.62 \pm 0.08$ and $7.12 \pm 0.57 \mathrm{mg} / \mathrm{dl}$, respectively. The $\mathrm{P}$ level in Group 3 cows on day $-14,+2$ and +30 were $6.30 \pm .0 .13,5.0 \pm 0.04$ and $6.36 \pm 0.07 \mathrm{mg} / \mathrm{dl}$, respectively. There were significant differences $(\mathrm{p}<0.05)$ within as well as between groups on day $-14,+2$ and +30 .

The serum Magnesium ( $\mathrm{Mg}$ ) level in Group 1 cows on day $-14,+2$ and +30 were $3.21 \pm 0.04$, $3.04 \pm 0.10$ and $3.48 \pm 0.36 \mathrm{mg} / \mathrm{dl}$, respectively. The $\mathrm{Mg}$ level in Group 2 cows on day $-14 .+2$ and +30 were $2.68 \pm 0.11,2.46 \pm 0.13$ and $3.32 \pm 0.06 \mathrm{mg} / \mathrm{dl}$, respectively.

The $\mathrm{Mg}$ level in Group 3 cows on day $-14,+2$ and +30 were 2.22 $\pm .0 .08,2.21 \pm 0.07$ and $3.27 \pm 0.05 \mathrm{mg} / \mathrm{dl}$, respectively. There were significant differences $(\mathrm{p}<0.05)$ within as well as between groups on day $-14,+2$ and +30 .

Decreased $\mathrm{Ca}$ and $\mathrm{P}$ level after parturition was due to occurrence of Milk Fever. But in Group 2 and Group 3; $\mathrm{Ca}$ and $\mathrm{P}$ level were within normal range but higher in comparison with control group, which might be due to feeding of anionic salts causing increased PTH hormone activity leading to proper reabsorption of $\mathrm{Ca}$ and $\mathrm{P}$ from bone and absorption from gut by synthesis of activated form of Vitamin $\mathrm{D}_{3}$.

Our findings are similar with the findings of Chan et al., (2005), Leno et al., (2017) and Radostits et al., (2006). Mg level was higher in Group 1 compared to Group 2 and Group 3 after parturition might be due to increase renal tubular reabsorption (Goff, 2006). 
Table.1 Therapeutic study model

\begin{tabular}{|l|c|c|}
\hline Group (n=6) & Therapy & Duration \\
\hline $\mathbf{1}$ & Positive Control i.e. healthy & On placebo \\
\hline $\mathbf{2}$ & Anionic salts $\left(\mathrm{NH}_{4} \mathrm{Cl}+\mathrm{CaSO}_{4}\right)$ & $\begin{array}{c}\mathrm{NH}_{4} \mathrm{Cl} @ \text { @ 45gm and } \mathrm{CaSO}_{4} @ 45 \mathrm{gm}, \\
\text { orally, mix with feeds, twice daily } \\
\text { from 3 weeks before parturition to day } \\
\text { of parturition. }\end{array}$ \\
\hline $\mathbf{3}$ & Hyporid & $\begin{array}{c}\mathrm{TM} \\
\end{array}$ \\
& & $\begin{array}{c}\text { Hyporid @ 90gm, Orally, mix with } \\
\text { feeds, twice daily from 3 weeks } \\
\text { before parturition to day of } \\
\text { parturition. }\end{array}$ \\
\hline
\end{tabular}

Table.2 Therapeutic efficacy of anionic salts and commercial salt preparation $\left(\right.$ Hyporid $^{\mathrm{TM}}$ ) in management of milk fever

\begin{tabular}{|l|l|l|l|}
\hline \multicolumn{1}{|c|}{ Group (n=6) } & \multicolumn{1}{|c|}{ Therapy } & $\begin{array}{c}\text { DCAD }(\mathbf{m E q} / \mathbf{1 0 0 g m} \\
\text { DM) }\end{array}$ & $\begin{array}{c}\text { Incidence of Milk } \\
\text { Fever }\end{array}$ \\
\hline Group 1 & Positive Control & +25.22 & $33.33 \%$ \\
\hline Group 2 & $\begin{array}{l}\text { Anionic salts } \quad\left(\mathrm{NH}_{4} \mathrm{Cl}\right. \\
\left.+\mathrm{CaSO}_{4}\right)\end{array}$ & -11.44 & $0 \%$ \\
\hline Group 3 & Hyporid $^{\mathrm{TM}}$ & -8.26 & \\
\hline & & & $0 \%$ \\
\hline
\end{tabular}


Table.3 Minerals and electrolytes Status (Mean \pm S.E.) in cow fed with rations supplemented with anionic salts

\begin{tabular}{|c|c|c|c|c|c|c|}
\hline \multirow{2}{*}{$\begin{array}{l}\text { Sl. } \\
\text { No }\end{array}$} & \multirow[t]{2}{*}{ Parameters } & \multirow{2}{*}{$\begin{array}{c}\text { Group } \\
(\mathbf{n}=6)\end{array}$} & \multicolumn{3}{|c|}{ Days } & \multirow{2}{*}{$\begin{array}{c}\text { Sig. } \\
(\mathbf{p}<0.05)\end{array}$} \\
\hline & & & $\begin{array}{c}14 \text { days before } \\
\text { parturition (- } \\
14)\end{array}$ & $\begin{array}{l}2 \text { days after } \\
\text { parturition } \\
(+2)\end{array}$ & $\begin{array}{l}30 \text { days after } \\
\text { parturition } \\
(+30)\end{array}$ & \\
\hline \multirow{4}{*}{1} & \multirow{4}{*}{$\begin{array}{l}\text { Calcium } \\
\text { (Ca) } \\
(\mathrm{mg} / \mathrm{dl})\end{array}$} & Group 1 & $7.81 \pm 0.10^{\mathrm{Aa}}$ & $6.90 \pm 0.13^{\mathrm{Ab}}$ & $7.30 \pm 0.17^{\mathrm{Ac}}$ & $\mathbf{S}^{* * *}$ \\
\hline & & Group 2 & $9.46 \pm 0.18^{\mathrm{Ba}}$ & $8.78 \pm 0.16^{\mathrm{Bb}}$ & $9.80 \pm 0.24^{\mathrm{Bc}}$ & $\mathbf{S}^{* * *}$ \\
\hline & & Group 3 & $9.70 \pm 0.26^{\mathrm{Ba}}$ & $9.81 \pm 0.24^{\mathrm{Ca}}$ & $10.60 \pm 0.18^{\mathrm{Cb}}$ & $\mathbf{S}^{* *}$ \\
\hline & & Sig. $(p<0.05)$ & $\mathbf{S}^{* * *}$ & $\mathbf{S}^{* * *}$ & $\mathbf{S}^{* *}$ & \\
\hline \multirow{4}{*}{2} & \multirow{4}{*}{$\begin{array}{l}\text { Phosphorus } \\
\text { (P) } \\
\text { (mg/dl) }\end{array}$} & Group 1 & $7.13 \pm 0.08^{\mathrm{Bc}}$ & $5.60 \pm 0.10^{\mathrm{Ba}}$ & $6.45 \pm 0.31^{\mathrm{Ab}}$ & $\mathbf{S}^{* * *}$ \\
\hline & & Group 2 & $7.10 \pm 0.09^{\mathrm{Bb}}$ & $6.62 \pm 0.08^{\mathrm{Ca}}$ & $7.12 \pm 0.57^{\mathrm{Bb}}$ & $\mathbf{S}^{* * *}$ \\
\hline & & Group 3 & $6.30 \pm 0.13^{\mathrm{Ab}}$ & $5.0 \pm 0.04^{\mathrm{Aa}}$ & $6.36 \pm 0.07^{\mathrm{Ab}}$ & $\mathbf{S}^{* * *}$ \\
\hline & & Sig. $(p<0.05)$ & $S^{* * *}$ & $S^{* * *}$ & $S^{* *}$ & \\
\hline \multirow{4}{*}{3} & \multirow{4}{*}{$\begin{array}{l}\text { Magnesium } \\
(\mathrm{Mg}) \\
(\mathrm{mg} / \mathrm{dl})\end{array}$} & Group 1 & $3.21 \pm 0.04^{\mathrm{Cb}}$ & $3.04 \pm 0.10^{\mathrm{Ba}}$ & $3.48 \pm 0.36^{\mathrm{Bc}}$ & $\mathbf{S} * *$ \\
\hline & & Group 2 & $2.68 \pm 0.11^{\mathrm{Ba}}$ & $2.46 \pm 0.13^{\mathrm{Aa}}$ & $3.32 \pm 0.06^{\mathrm{Ab}}$ & $S^{* * *}$ \\
\hline & & Group 3 & $2.22 \pm 0.08^{\mathrm{Aa}}$ & $2.21 \pm 0.07^{\mathrm{Aa}}$ & $3.27 \pm 0.05^{\mathrm{Ab}}$ & $\mathbf{S}^{* *}$ \\
\hline & & Sig. $(p<0.05)$ & $\mathbf{S}^{* * *}$ & $S^{* * *}$ & $S^{* * *}$ & \\
\hline \multirow{4}{*}{4} & \multirow{4}{*}{$\begin{array}{l}\text { Sodium (Na) } \\
(\mathrm{mEq} / \mathrm{L})\end{array}$} & Group 1 & $132.97 \pm 1.27^{\mathrm{Aa}}$ & $154.57 \pm 1.53^{\mathrm{Ab}}$ & $143.46 \pm 1.34^{\mathrm{Ab}}$ & $\mathbf{S}^{* *}$ \\
\hline & & Group 2 & $135.87 \pm 1.76^{\mathrm{Aa}}$ & $142.59 \pm 2.60^{\mathrm{Bb}}$ & $140.70 \pm 1.05^{\mathrm{Ab}}$ & $S^{* * *}$ \\
\hline & & Group 3 & $133.79 \pm 1.35^{\mathrm{Aa}}$ & $139.37 \pm 1.14^{\mathrm{Bb}}$ & $136.36 \pm 1.61^{\mathrm{Bb}}$ & $\mathbf{S}^{*}$ \\
\hline & & Sig. $(p<0.05)$ & NS & $S^{* * *}$ & $S^{*}$ & \\
\hline \multirow{4}{*}{5} & \multirow{4}{*}{$\begin{array}{l}\text { Potassium } \\
(\mathrm{K}) \\
(\mathrm{mEq} / \mathrm{L})\end{array}$} & Group 1 & $5.34 \pm 0.04^{\mathrm{Cb}}$ & $5.75 \pm 0.14^{\mathrm{Aa}}$ & $5.19 \pm 0.11^{\mathrm{Ab}}$ & $\mathbf{S}^{* *}$ \\
\hline & & Group 2 & $4.57 \pm 0.09^{\mathrm{Aa}}$ & $5.21 \pm 0.11^{\mathrm{Bb}}$ & $5.08 \pm 0.12^{\mathrm{Ab}}$ & $\mathbf{S}^{* * *}$ \\
\hline & & Group 3 & $4.9 \pm 0.14^{\mathrm{Ba}}$ & $5.22 \pm 0.30^{\mathrm{Bb}}$ & $5.14 \pm 0.09^{\mathrm{Ab}}$ & $\mathbf{S}^{* * *}$ \\
\hline & & Sig. $(p<0.05)$ & $\mathbf{S}^{* * *}$ & $\mathbf{S}^{* * *}$ & NS & \\
\hline \multirow{4}{*}{6} & \multirow{4}{*}{$\begin{array}{l}\text { Chloride } \\
(\mathrm{Cl}) \\
(\mathrm{mEq} / \mathrm{L})\end{array}$} & Group 1 & $88.80 \pm 0.98^{\mathrm{Aa}}$ & $85.78 \pm 0.97^{\mathrm{Aa}}$ & $91.89 \pm 1.22^{\mathrm{Ab}}$ & $\mathbf{S}^{* *}$ \\
\hline & & Group 2 & $101.12 \pm 0.75^{\mathrm{Ba}}$ & $99.0 \pm 0.97^{\mathrm{Ba}}$ & $101.22 \pm 0.77^{\mathrm{Ba}}$ & NS \\
\hline & & Group 3 & $99.58 \pm 0.35^{\mathrm{Bba}}$ & $98.30 \pm 0.90^{\mathrm{Ba}}$ & $98.34 \pm 0.35^{\mathrm{Ba}}$ & NS \\
\hline & & Sig. $(p<0.05)$ & $\mathbf{S}^{* * *}$ & $\mathbf{S}^{* * *}$ & $\mathbf{S}^{* * *}$ & \\
\hline \multirow{4}{*}{7} & \multirow{4}{*}{$\begin{array}{l}\text { Sulphate (S) } \\
(\mathrm{mmol} / \mathrm{l})\end{array}$} & Group 1 & $0.60 \pm 0.01^{\mathrm{Ab}}$ & $0.49 \pm 0.01^{\mathrm{Aa}}$ & $0.62 \pm 0.01^{\mathrm{Ab}}$ & $\mathbf{S}^{* * *}$ \\
\hline & & Group 2 & $0.64 \pm 0.01^{\mathrm{Bb}}$ & $0.59 \pm 0.01^{\mathrm{Ba}}$ & $0.71 \pm 0.01^{\mathrm{Bc}}$ & $\mathbf{S}^{* *}$ \\
\hline & & Group 3 & $0.64 \pm 0.01^{\mathrm{Bb}}$ & $0.52 \pm 0.02^{\mathrm{Aa}}$ & $0.69 \pm 0.02^{\mathrm{Bc}}$ & $\mathbf{S}^{* *}$ \\
\hline & & Sig. $(p<0.05)$ & $S^{*}$ & $S^{* * *}$ & $\mathbf{S}^{* *}$ & \\
\hline
\end{tabular}

*Significant at $5 \%(\mathrm{p}<0.05)$

$* *$ Significant at $1 \%(\mathrm{p}<0.01)$

$\mathrm{n}=$ No. of animals each group

Same symbol in superscript do not differ significantly. For row wise comparison small letter have been used in superscript. And for column wise comparison capital letter have been used in superscript. 
The serum Sodium (Na) level in Group 1 cows on day $-14,+2$ and +30 were $132.97 \pm 1.27,154.57 \pm 1.53$ and $143.46 \pm 1.34$ $\mathrm{mEq} / \mathrm{L}$, respectively. The Na level in Group 2 cows on day -14 . +2 and +30 were $135.87 \pm 1.76,142.59 \pm 2.60$ and $140.70 \pm 1.05$ $\mathrm{mEq} / \mathrm{L}$, respectively. The $\mathrm{Na}$ level in Group 3 cows on day $-14,+2$ and +30 were $133.79 \pm .1 .35,139.37 \pm 1.14$ and $136.36 \pm 1.61$ $\mathrm{mEq} / \mathrm{L}$, respectively. There were significant differences $(\mathrm{p}<0.05)$ within as well as between groups on day $-14,+2$ and +30 except between groups on day -14 .

The serum Potassium (K) level in Group 1 cows on day $-14,+2$ and +30 were $5.34 \pm 0.04$, $5.75 \pm 0.14$ and $5.19 \pm 0.11 \quad \mathrm{mEq} / \mathrm{L}$, respectively. The $\mathrm{K}$ level in Group 2 cows on day $-14 .+2$ and +30 were $4.57 \pm 0.09$, $5.21 \pm 0.11$ and $5.08 \pm 0.12 \mathrm{mEq} / \mathrm{L}$, respectively. The $\mathrm{K}$ level in Group 3 cows on day $-14,+2$ and +30 were 4.90土.0.14, $5.22 \pm 0.30$ and $5.14 \pm 0.09 \quad \mathrm{mEq} / \mathrm{L}$, respectively. There were significant differences $(\mathrm{p}<0.05)$ within as well as between groups on day $-14,+2$ and +30 except between groups on day +30 .

The serum Chloride $(\mathrm{Cl})$ level in Group 1 cows on day $-14,+2$ and +30 were $88.80 \pm 0.98, \quad 85.78 \pm 0.97$ and $91.89 \pm 1.22$ $\mathrm{mEq} / \mathrm{L}$, respectively. The $\mathrm{Cl}$ level in Group 2 cows on day $-14+2$ and +30 were $101.12 \pm 0.75,99.0 \pm 0.97$ and 101.22 \pm 0.77 $\mathrm{mEq} / \mathrm{L}$, respectively. The $\mathrm{Cl}$ level in Group 3 cows on day $-14,+2$ and +30 were $99.58 \pm 0.35, \quad 98.30 \pm 0.90$ and $98.34 \pm 0.35$ $\mathrm{mEq} / \mathrm{L}$, respectively. There were significant differences $(\mathrm{p}<0.05)$ within as well as between groups on day $-14,+2$ and +30 except within Group 2 and Group 3 on day $14,+2$ and +30 .

The serum Sulphate $(\mathrm{S})$ level in Group 1 cows on day $-14,+2$ and +30 were $0.60 \pm 0.01$, $0.49 \pm 0.01$ and $0.62 \pm 0.01 \mathrm{mmol} / \mathrm{L}$, respectively. The $S$ level in Group 2 cows on day $-14 .+2$ and +30 were $0.64 \pm 0.01$, $0.59 \pm 0.01$ and $0.71 \pm 0.01 \quad \mathrm{mEq} / \mathrm{L}$, respectively. The $S$ level in Group 3 cows on day $-14,+2$ and +30 were $0.64 \pm 0.01$, $0.52 \pm 0.02$ and $0.69 \pm 0.02 \mathrm{mmol} / \mathrm{L}$, respectively. There were significant differences $(p<0.05)$ within as well as between groups on day $-14,+2$ and +30 .

Significant increase in $\mathrm{Na}$ and $\mathrm{K}$ level in Group 1 compared to Group 2 and Group 3 might be due to less feed and water intake and high content of cations in feed. In Group 2 and Group 3, Cl and S level significantly increased compared to Group 1 might be due to feeding anionic salts as a result level of anions in blood got increased. These findings corresponded with the reports of Tucker et al., (1990), Oetzel (1993) and Wang et al., (1994) who reported anions i.e. chloride and sulphate can directly acidify biological fluids and alter acid-base balance strongly if included at high dietary concentrations.

\section{Acknowledgment}

The help rendered by Dr J. K. Chaudhury (Asst. Professor, AGB) and Dr A. K. Samanta (Professor and Head, ANN), College of Veterinary Sciences and Animal Husbandry, Selesih, Aizawl, Central Agriculture University, Mizoram for statistical analysis and DCAD estimation in the present study is duly acknowledged.

\section{References}

Chan, P. S., West, J. W., Bernard, J. K., and Fernandez, J. M. (2005). Effects of dietary cation-anion difference on intake, milk yield, and blood components of the early lactation cow. J. dairy Sci. 88(12), 4384-4392.

Curtis, C. R., Erb, H. N., Sniffen, C. J., Smith, R. D. and Kronfeld, D. S. (1985). Path 
analysis of dry period nutrition, postpartum metabolic and reproductive disorders, and mastitis in holstein cows. J. Dairy Sci., 68(9): 2347-2360.

Gelfert, C.C., Loeffler, L.M., Frömer, S., Engel, M., Männer, K. and Staufenbiel, R. (2010). Comparison of the impact of different anionic salts on the acid-base status and calcium metabolism in nonlactating, non-pregnant dairy cows. The Vet. J. 185(3): 305-309.

Goff, J. P. (2006). Macromineral physiology and application to the feeding of the dairy cow for prevention of milk fever and other periparturient mineral disorders (Special Issue: Feed and animal health.). Anim. Feed Sci. and Tech. 126 (3): 237-257,

Goff, J. P. and Horst, R. L. (2003). Role of acid-base physiology on the pathogenesis of parturient hypocalcaemia (milk fever) the DCAD theory in principal and practice. Acta. Vet. Scand. Suppl., 97: 51-56.

Goff, J. P., Ruiz, R. and Horst, R.L. (2004). Relative acidifying activity of anionic salts commonly used to prevent milk fever. J. Dairy sci., 87(5):1245-1255.

Leno, B. M., Ryan, C. M., Stokol, T., Kirk, D., Zanzalari, K. P., Chapman, J. D., and Overton, T. R. (2017). Effects of prepartum dietary cation-anion difference on aspects of peripartum mineral and energy metabolism and performance of multiparous Holstein cows. J. dairy Sci, 100(6), 4604-4622.
Oetzel, G. R. (1993). Use of anionic salts for prevention of milk fever in dairy cattle. Comp. Cont. Educ, Pract. Veterinarian: Food Animals 15: 1138-1146.

Radostits, O. M., Gay, C., Blood, C. and Kenneth, W. (2006). Metabolic disturbance. Veterinary Medicine, $10^{\text {th }}$ edn, Baillire Tindal publisher, London, pp. 1627-1642.

Rajala-Schultz, P.J., Grohn, Y.T. and Meculloch, C.E. (1999). Effect of milk fever, ketosis and lameness on milk yield in dairy cows. J Dairy Sci., 82: 288-294.

Seifi, H.A., Mohri, M., Farzaneh, N., Nemati, H. and Nejhad, S.V. (2010). Effects of anionic salts Supplementation on blood $\mathrm{pH}$ and mineral status, energy metabolism, reproduction and production in transition dairy cows. Research in Vet. Sci. 89(1): 72-77.

Tucker, W. B., Hogue, J. F., Waterman, D. F., Swenson, T. S., Xin, Z., Hemken, R. W., Jackson, J. A., Adams, G. D. and Spicer, L. J. (1990). Role of sulfur and chloride in the dietary cation-anion balance equation for lactating dairy cattle. J. Ani. Sci. 69: 1205-1213.

Wang, C., Velez, J. S.,, Risco, C. A., Donovan, G. A., Merritt, A. M. and Beede, D. K. (1994). Recent advances in prevention of parturient paresis in dairy cows. Comp. Cont. Educ. Pract. Veterinarian: Food Animals 16: 13731381.

\section{How to cite this article:}

Arindam Bhowmik, Gunjan Das, Hriyadesh Prasad, Kalyan Sarma, A.K. Samanta, Bikash Debnath, J.K. Chaudhary, Prasenjit Debnath, Albert Debbarma and Moneesh Thakur. 2019. Minerals and Electrolytes Status in Cows Fed on Rations Supplemented with Anionic Salts in Pre-Partum Period in Prevention of Milk Fever. Int.J.Curr.Microbiol.App.Sci. 8(07): 25302536. doi: https://doi.org/10.20546/ijcmas.2019.807.312 